\title{
Control Analysis of Medicine Inventories Using ABC, VEN, and EOQ Approach in Pharmaceutical Companies
}

\section{Indra Almahdy ${ }^{1}$, Muhammad Kholil ${ }^{1}$, Jakfat Haekal ${ }^{1}$ and Tri Widodo ${ }^{2}$}

\author{
${ }^{1}$ Department of Industrial Engineering, Universitas Mercu Buana, DKI Jakarta, Indonesia
}

\author{
2Universitas Islam Muhammadiyah Tanggerang, DKI Jakarta, Indonesia
}

*Corresponding author details: Indra Almahdy; indraal@mercubuana.ac.id

\begin{abstract}
Pharmaceutical Companies is a place for people to get health services. One unit that has an important role is the Pharmacy division. Pharmacy services include patient care and are responsible for the provision of medicines and other medical devices. This study aimed to find the control of Medicine supplies in sufficient quantities, at the time needed and at the lowest cost. Management of Medicine supplies can be done using the Always, Better, and Control (ABC) method and the Vital, Essential, and Non-Essential (VEN) method to determine priorities in Medicine procurement so that funds are used efficiently. Furthermore, the EOQ (Economic Order Quantity) calculation is carried out to obtain optimal inventory.
\end{abstract}

Keywords: inventory; medicine; ABC; VEN; EOQ

\section{INTRODUCTION}

The development in the manufacturing industry is increasing; this can be seen from the very tight business competition. So that companies can remain competitive, the use of technology is very influential in making products relatively cheaper, and thus the demand for products will certainly increase. Companies will compete to meet customer demand by increasing the amount of production. However, setting the amount of inventory that is too much will result in wasteful storage costs. Setting the amount of inventory that is too small also results in a loss of opportunities for profit if customer demand exceeds the demand estimated by the company. The two dilemmas in determining "how much" the amount of inventory that must be provided and "when" should be provided will be discussed in this study, so that this decision can minimize the costs that the company must incur. In Kushartini \& Almahdy's research (2016), Assauri revealed that controlling material inventory is an activity to determine the level and composition of the inventory of parts, raw materials and products or products, so that companies can protect the smooth running of production and sales as well as the company's spending needs effectively and efficient.

Managing the inventory level or stock level is fundamental in forming the company's long-term competitive advantage to satisfy consumer desires.
Therefore, it is necessary to pay attention to the implementation of a material control system so that production can run smoothly in order to satisfy consumer desires. In controlling material supplies, it is necessary to have an appropriate system or method to create effectiveness and efficiency within the company to generate profits instead of causing losses.

Different types of products with different marketing of these products have been marketed to various cities in Indonesia. There is a large inventory of raw materials, but the main raw material is raw materials in this research. According to Wulandari, S.dkk (2019) The ABC VEN method has advantages over other methods, namely the ABC VEN method can find out consumption patterns for all types of Medicines and their funds, can find out types of Medicines that require more supervision because of their high investment value and group them according to their investment value., can determine Medicine purchase priorities along with the Medicine sales price. So, this research uses the comparison of the $\mathrm{ABC}$ method and the VEN method to determine the value of the material stock level (stock level) that is effective and efficient. The following is Medicine supply data for 2018 to 2020 .

TABLE 1: Data on The Types of Medicine Supplies In 2020

\begin{tabular}{|c|c|c|c|c|c|c|}
\hline \multicolumn{7}{|c|}{ MEDICINE SUPPLY IN 2020} \\
\hline No. & Type of Medicine & Packaging & Demand & Price & & Total Price \\
\hline 1 & Lopiten 10mg & BOX & 17 & Rp 285,000.00 & $\mathrm{Rp}$ & $4,845,000.00$ \\
\hline 2 & Govazol 150mg & BOX & 25 & Rp 225,000.00 & $\mathrm{Rp}$ & $5,625,000.00$ \\
\hline 3 & Fuladic Cream 5gr & TUB & 515 & $\mathrm{Rp} \quad 53,000.00$ & $\mathrm{Rp}$ & $27,295,000.00$ \\
\hline 4 & Loran 10mg & BOX & 28 & Rp $159,000.00$ & $\mathrm{Rp}$ & $4,452,000.00$ \\
\hline 5 & Thecort Cream 5gr & TUB & 148 & Rp $54,000.00$ & $\mathrm{Rp}$ & $7,992,000.00$ \\
\hline
\end{tabular}




\begin{tabular}{|c|c|c|c|c|c|c|}
\hline \multicolumn{7}{|c|}{ MEDICINE SUPPLY IN 2020} \\
\hline No. & Type of Medicine & Packaging & Demand & Price & \multicolumn{2}{|c|}{ Total Price } \\
\hline 6 & Cupanol 60ml & BOTTLE & 20 & Rp $19,000.00$ & $\mathrm{Rp}$ & $380,000.00$ \\
\hline 7 & Fungasol 80ml & BOTTLE & 30 & $\mathrm{Rp} 50,000.00$ & $\mathrm{Rp}$ & $1,500,000.00$ \\
\hline 8 & Elox Cream 10gr & TUB & 12 & $\mathrm{Rp} 72,000.00$ & $\mathrm{Rp}$ & $864,000.00$ \\
\hline 9 & Dhavit Syrup 60ml & BOTTLE & 15 & $\mathrm{Rp} 32,000.00$ & $\mathrm{Rp}$ & $480,000.00$ \\
\hline 10 & Zibramax $15 \mathrm{ml}$ & BOTTLE & 30 & Rp 103,000.00 & $\mathrm{Rp}$ & $3,090,000.00$ \\
\hline 11 & Fungares $80 \mathrm{ml}$ & BOTTLE & 34 & $\mathrm{Rp} 50,000.00$ & $\mathrm{Rp}$ & $1,700,000.00$ \\
\hline 12 & Unalium 10mg & BOX & 40 & Rp 320,000.00 & $\mathrm{Rp}$ & $12,800,000.00$ \\
\hline 13 & Rydian 10mg & $\mathrm{BOX}$ & 43 & Rp 132,000.00 & $\mathrm{Rp}$ & $5,676,000.00$ \\
\hline 14 & Hustadin $60 \mathrm{ml}$ & BOTTLE & 927 & $\operatorname{Rp} 16,500.00$ & $\mathrm{Rp}$ & $15,295,500.00$ \\
\hline \multicolumn{5}{|c|}{ TOTAL } & \multicolumn{2}{|c|}{ Rp91,994,500.00 } \\
\hline
\end{tabular}

30000000

MEDICINE SUPPLY IN 2020

25000000

20000000

15000000

10000000

5000000

0

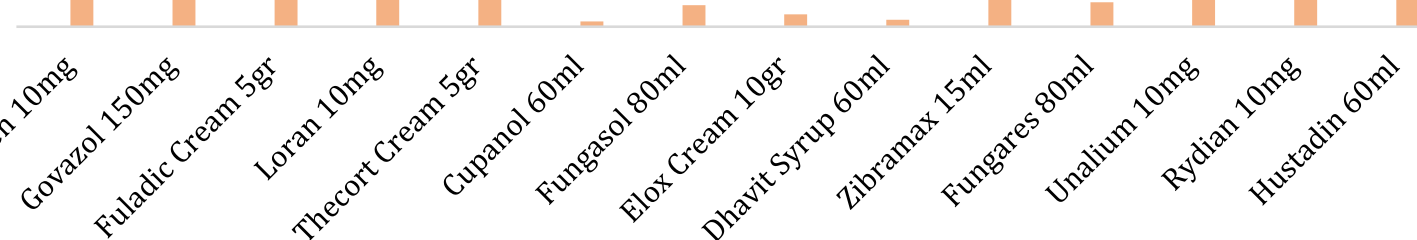

FIGURE 1: Data on types of drug supplies in 2020

Based on the graph, the amount of inventory is unstable, there is a small amount of stock and there is also a large amount of remaining stock that does not match the amount of use. This condition is not good in terms of cost and storage, so it must be minimized. Therefore, an inventory control method is needed to control medicinal raw materials. Several methods that can be used to control inventory levels are the ABC method and the VEN method.

\section{RESEARCH METHODOLOGY}

\section{Type of Research}

This study, using quantitative research methods because, in practice, it covers data in the form of numbers or numbers. By its form, quantitative data can be processed or analyzed using mathematical calculation techniques.

\section{Types of Data and Information}

The types of data and information used to obtain data in this paper are:

\section{- Field research (Field Research)}

Field research is a form of research carried out using observation, interviews, to obtain more precise and reliable data according to the needs needed to support this writing. The data is in the form of primary data and secondary data.

a) Primary data, namely data obtained directly in the field. In this study, data were obtained by interviewing local employees. b) Secondary data, namely previously processed data, the authors only quote from existing data based on company documentation.

\section{- Library Research}

Literature research is a literature study closely related to the issues to be discussed, including planning and controlling raw material supplies, the $\mathrm{ABC}$ method, and the VEN method.

\section{Data Collection Methods}

The data collection methods used to obtain inventory data for the types of drugs in 2018-2020 at PT. XYZ in this writing are:

Researchers used several data collection techniques as follows:

1) Observation Data collection by observing directly the location of the research site.

2) Interview is a data collection technique conducted through face-to-face and direct question and answer between data collectors and researchers to sources or data sources. In this study, researchers interviewed employees at the company.

3) Documentation Collecting data by recording or copying company data in accordance with the problem under study. 


\section{Processing and Data Analysis Methods}

This study uses the ABC supply control method, the VEN method by combining the two methods, so it requires several stages, namely:

1) Analysis of drug supply requirements at PT. XYZ At this stage, an analysis of the order/needs of the drug is an order quantity. In the study of drug needs, research defines:

a. How much medicine is needed

b. What is the cost and total cost of drug supplies

2) Suggestions for standard determination of drug stock levels

At this stage, determining the standard for determining drug stock levels based on the order quantity and the minimum total cost of research supplies requires several steps.

The steps taken by the determination are:

a. Determining the amount of drug supply that is more efficient at PT. XYZ.

b. Knowing the total cost of drug supplies at PT. XYZ is more efficient

\section{EOQ}

The EOQ model is one of the oldest and best-known inventory control techniques. This technique is relatively easy to use, but based on assumptions, namely:

1) The number of requests per period is known.

2) The waiting time ie the time between ordering and receiving the order is known and constant.

3) Inventory receipt is instantaneous and completely completed. In other words the inventory of an order comes in one batch at a time.

4) There is no discount for large purchases

5) Out of stock can be completely avoided if the order is made at the right time.

\section{Safety Stock}

Safety stock or safety stock serves to protect errors in predicting demand during the lead time. The safety stock will function if the real demand is greater than the average value. The value of the safety stock depends on the uncertainty of supply and demand. In normal situations, supply uncertainty can be represented by the standard deviation of the lead time from the supplier, which is the time between the company ordering until the materials or goods are received. Meanwhile, demand uncertainty is usually represented by the standard deviation of the demand per period. If the demand per period and lead time are both constant, no safety stock is needed because the demand during the lead time has zero standard deviation. (Nyoman Pujawan, 2005)

\section{Reorder Point (ROP)}

In addition to determining EOQ, inventory control also determines when to place an order or buyback. Purchasing or ordering, do not wait until the inventory runs out, because if that happens it will disrupt the continuity of production. Determining when to place an order is called a Reorder Point (ROP), which is the time when the company or production manager has to make another purchase of materials. This is necessary because the raw material orders are not always sent immediately by the supplier, so it may take several hours

\section{RESULT AND DISCUSSION \\ ABC Analysis}

The Always, Better Control (ABC) analysis method is making groups or classifications based on the highest to the lowest number of drug consumption. This method is critical to focus the company's attention to determine the types of drugs prioritized in the inventory. The number of drug consumption in the company reached 1,840 drugs in 2020.

Based on the results of the $\mathrm{ABC}$ analysis, it is known that the drugs classified as A classification are $68.9 \%$ consisting of 4 types of drugs based on the investment value in the company. Classification A must-have tighter inventory control, more verification accuracy of records, and tighter physical supervision, which is carried out every month.

Drugs included in Classification A with the most significant investment value must be a concern for the company. Classification A is a very critical group of drugs. The investment value for Classification $\mathrm{B}$, which is equal to Classification $B$, is only $1.9 \%$ of the investment value.

\section{VEN Analysis}

The VEN method is used to categorize drugs by considering the criticality level of the drug. Of the 14 types of drugs in the company that is included in the Vital (V) category based on their criticality level, there are 11 types of drugs.

Based on the results of grouping the types of drugs obtained based on interviews with selected informants, namely the Head of the Pharmacy Installation of the drug company, the drug company is said to be vital because it is included in the category of life-saving drugs, meaning that these drugs must always be available in the Pharmacy section. If there is a vacuum when the drug is needed, it will result in death in the patient, so it can be said to be the first aid drug in an emergency.

\section{Analysis of EOQ, Safety Stock and Reorder Point}

Inventory control is carried out due to drug stock out which results in the purchase of drugs in a cito (sudden purchase of drugs). This risks increasing costs due to drug purchases made at other distributors and decreasing patient satisfaction levels due to drugs not being available when the drug is needed. From the EOQ calculation on the 11 drugs with existing Vital categories, it was obtained that the optimal Q value was different for each type. This is because the value of $Q$ is influenced by other demands for each drug, ordering costs and holding costs. The amount of the optimal $Q$ value is directly proportional to the demand and cost of the message, but inversely proportional to the storage cost. The greater the storage cost, the smaller the number of orders for drugs, this is done to reduce costs due to storing drugs in warehouses. From the results of inventory calculations using the EOQ method, the highest order quantities were 10 items for $60 \mathrm{ml}$ Cupanol medicine and the lowest EOQ values were 3 items for Govazol $150 \mathrm{mg}$ and $10 \mathrm{mg}$ unalium drugs. Another thing that needs to be done to anticipate a surge in demand is to provide safety supplies.

Safety stock is useful for protecting the company from the risk of running out of drugs (Stock Out) and delays in receiving the ordered drugs. Safety Stock is needed to reduce losses caused by the occurrence of Stock Out, but at the level of inventory can be reduced to a minimum, therefore the company needs to make calculations to determine the most optimal Safety Stock to determine the amount of safety stock required. From the calculation results, the largest amount of Safety Stock is found in the drug Govazol $150 \mathrm{mg}$, Loran $10 \mathrm{mg}$, Unalium $10 \mathrm{mg}$ and Rydian $10 \mathrm{mg}$. Safety stock should not run out while waiting for the next order to arrive.

The time of reorder or Reorder Point is the time when the company must order the drug again, so that the receipt of the ordered drug can be on time. This is because ordering drugs cannot be immediately accepted that day. What is meant by Lead Time is the grace period required between 
the time the drug order is made and the time the ordered medicine arrives. The highest reorder point is in the $10 \mathrm{mg}$ Unalium drug for 9 items, so it is necessary to order Unalium Medicine when the stock reaches 9 items.

\section{CONCLUSION}

The conclusions from the results of the calculations carried out are as follows:

1) Based on the $A B C$ analysis, there are 4 types of drugs included in group A (Always) with a total investment of $68.9 \%$ of the total drug use, Group B (Better) as many as 7 types of drugs with a total investment of $29.2 \%$ of the total drug use, and group C (Control) with 3 types of drugs with a total investment of $1.9 \%$ of the total drug use.

2) Based on the VEN analysis for drugs belonging to group $A$, the number of drugs included in group V (Vital) was 11 out of a total of 4 types of drugs from group A.

3) Based on the analysis of the inventory count, the description for 14 types of drugs included in group $\mathrm{V}$ shows that the optimum order quantity (EOQ) varies from 3-11 units for each type of drug. The number of safety stock varies from 0-7 units for each type of drug and the points for reordering the ROP also vary from 19 units for each type of drug.

\section{SUGGESTION}

Suggestions for this research are as follows:

1) We recommend that companies do accurate forecasting and planning in drug purchases so that drug Stock Out does not occur.

2) Creating a management information system with an up to date database for planning and controlling inventory to minimize delays in drug procurement which are still managed manually.

3) It is advisable for further research to conduct inventory control models for other category drugs such as the $\mathrm{AE}$ category.

\section{REFERENCES}

[1] Adrianto, W., \& Kholil, M. (2016). Analisis Penerapan Lean Production Process untuk Mengurangi Lead Time Process Perawatan Engine (Studi Kasus PT.GMF AEROASIA). Jurnal Optimasi Sistem Industri, 14(2), 299. https://doi.org/10.25077/josi.v14.n2.p299-309.2015

[2] Dambhare, S., Aphale, S., Kakade, K., Thote, T., \& Jawalkar, U. (2013). Reduction in rework of an engine step bore depth variation using DMAIC and Six Sigma approach: A case study of engine manufacturing industry. International Journal of Advanced Scientific and Technical Research, 3(2), 252-263.

[3] Gaspersz, v. (2010). Total Quality Management (TQM). PT Gramedia Pustaka Utama.

[4] Gaspersz, v. (2013). All-In-One Integrated Total Quality Talent Management. PR Percetakan DKU.

[5] Gaspersz, v, \& Fontana. (2007). Lean Six Sigma for Manufacturing and Services Industries. PT Gramedia Pustaka Utama.

[6] Guo, W., Jiang, P., Xu, L., \& Peng, G. (2019). Integration of value stream mapping with DMAIC for concurrent Lean-Kaizen: A case study on an air-conditioner assembly line. Advances in Mechanical Engineering, 11(2), 1-17.

https://doi.org/10.1177/1687814019827115
[7] Haryanto, E., \& Bonivasius, P. (2019). ANALISA PENURUNAN CACAT (DEFECT) CAT BINTIK DEBU DENGAN METODOLOGI SIX SIGMA PADA PROSES PAINTING PRODUK FUEL TANK DI PT. SSO TANGERANG 1 Endi Haryanto dan 2 Bonivasius Prasetya Ichtiarto. XIII (3), 326-337.

[8] Haekal, J., \& Setio, H. 2017. Selection of Raw Material Suppliers Using Analytical Hierarchy Process in Food and Beverage Company, South Jakarta. ComTech: Computer, Mathematics and Engineering Applications, 8(2), 63-68.

[9] HAEKAL, J. (2018). PERANCANGAN DAN EVALUASI IMPLEMENTASI SISTEM MANAJEMEN MUTU ISO 9001: 2015 MELALUI KEPUASAN PELANGGAN DI UNIVERSITAS ISLAM AS-SYAFI'IYAH (Doctoral dissertation, Universitas Mercu Buana Jakarta).

[10] Kholil, M., Haekal, J. H, Sulaiman. 2020. Lean Manufacturing Design to Reduce Waste in Gear Production Process Using VSM and Kaizen Method Approaches (Case Study: Gear Primary Driven K56 Product). Journal of Scientific and Engineering Research. 7(8), 1-9

[11] Haekal, J., \& Prasetio, D. E. A. Planning of Production Facilities Layouts in Home Industry with The Systematic Layout Planning Method.

[12] haekal, J., \& Setiawan, I. (2020). Comparative Analysis of Raw Materials Control Using JIT and EOQ method For Cost Efficiency of Raw Material Supply in Automotive Components Company Bekasi, Indonesia. International Journal of Engineering Research and Advanced Technology (ijerat), 6(10), 76-82.

https://doi.org/10.31695/IJERAT.2020.366

[13] Hidayat, A. A., Kholil, M., Hendri, \& Suhaeri. (2018). The Implementation of FTA (Fault Tree Analysis) and FMEA (Failure Mode and Effect Analysis) Methods to Improve the Quality of Jumbo Roll Products. IOP Conference Series: Materials Science and Engineering, 453(1). https://doi.org/10.1088/1757-899X/453/1/012019

[14] Kholil, M, \& Syukron. (2013). SIX SIGMA: Quality for Business Improvement. Graha Ilmu.

[15] Kholil, M, Syukron, \& Amin. (2013). Six Sigma for Business Improvement. Graha Ilmu.

[16] Kholil, Mohammad, \& Prasetyo, E. D. (2017). Tinjauan Kualitas Pada Aerosol Can $\emptyset 65$ X 124 Dengan Pendekatan Metode Six Sigma Pada Line Abm 3 Departemen Assembly. Sinergi, 21(1), 53. https://doi.org/10.22441/sinergi.2017.1.008

[17] Kholil, Muhammad, \& Pambudi, T. (2010). Implementasi Lean Six Sigma Dalam Peningkatan Kualitas Dengan Mengurangi Produk Cacat Ng Drop Di Mesin Final Test Produk HI 4.8 Di Pt. Ssi. Jurnal PASTI.

[18] Matathil, A., N, G. K., \& Ramachandran, K. (2012). Reduction of Scrap in an Electronic Assembly Line Using DMAIC Approach. SASTECH Journal, 11(2), 53-59.

[19] McDermott, \& Robbin, E. (2009). The Basics of FMEA 2nd Edition. Taylor \& Francis Group.

[20] Muhsin, A., Djawoto, Susilo, P., \& Muafi. (2018). Hospital performance improvement through the hospital information system design. International Journal of Civil Engineering and Technology, 9(1), 918-928. 
[21] Prasetyo, E. D. (2015). Analisa produksi pada AEROSOL CAN Ø 65 X 124 DENGAN MENGGUNAKAN METODE PENDEKATAN SIX SIGMA PADA. VIII (2), 191-202.

[22] Syaifulloh. (2014). Analisa Pengendalian Kualitas Aerosol Can dengan Menggunakan Metode DMAIC pada Line ABM 1 di Perusahaan Perkalengan Indonesia. Jurnal PASTI, viii, 340-348.
[23] Tannady. (2015). Pengendalian Kualitas. Graha Ilmu.

[24] Uddin, S. M., \& Rahman, C. M. L. (2014). Minimization of Defects in the Sewing Section of a Garment Factory through DMAIC Methodology of Six Sigma. Research Journal of Engineering Sciences, 3(9), 21-26.

[25] Wahyuni, H. C. (2015). Pengendalian Kualitas. Graha Ilmu. 